\title{
Dancing bodies as impulses for democracy: A Dance Philosophical Approach on Body-Thinking
}

\author{
Aurelia Baumgartner \\ AurelianaContemporaryDanceProject \\ School of Contemporary Dance \\ Berg / Munich, Germany \\ aurelia@tanzphilosophie.de
}

Received 30 July 2020; accepted 27 November 2021; published 28 December 2021.

\begin{abstract}
In my paper, I discuss the question whether dancing bodies might be relevant for democracy. I will refer to the recently created performance, Dancing bodies as impulses for democracy? (Subsidized by the city of Starnberg and premiered in April 2019 in 'Schlossberghalle' Starnberg, Germany). I explain my approach with reference to the semiotic philosophy of Charles Sanders Peirce, relating Peirce's categories to that performance. I discuss whether dancing bodies open a path to a pre-symbolic area. In this pre-symbolic area, the image of bodies does not pose relevance yet. I explore the idea that this pre-symbolic area opens a space for communication and mode of imagining as well as thinking. Communication, the mode of imagining and thinking are thereby possibly not yet influenced by final categories. This opens the opportunity for images, habitually coded by pre-fixed structures, to become intangible, blurred and therefore deconstructed. Moreover, the pre-symbolic area I am exploring opens the possibility for disciplinary structuresto be recognized and dissolved. The subject thereby gets access to a mode, which I call transversality ${ }^{\prime}$, where transversality here is a realm open to differences and thereby to 'transversal freedom'. More importantly, I discuss my approach to dance philosophy as well as to performance philosophy, which I have been researching and developing over a long period of time. This approach I call body-thinking (Baumgartner, 2016, pp. 8-13). Body-thinking is not my invention: it is mentioned in many contexts concerning body intelligence. However, as I am using it, body-thinking, on the one hand, is meant to be body intelligence, but on the other hand there is emphasis on a semiotic structure of quality of

\footnotetext{
1 'Transversaliy' is a term which in philosophy is used by various authors. Here I am influenced by Wolfgang Welsch's elaboration of a 'Transversal reason', which means the faculty of judgement effectuating transitions between multiple modes of reason. Welsch's transversal reason is an answer to Lyotard's multiple notion of knowledge in postmodern society. I use it in analogy to that, emphasizing a sort of energetic transition in sensing-feeling-perceiving the other and vice-versa by a border opening movement between I and other.
} 
feelings as firstness, impulse-resistance as dyadic relation (called secondness), and structure as thirdness. It means to thematize the body as sign creating entity by a mode of moving, feeling, perceiving to realize thinking - as a thinking-in-motion with enhanced perception, and its structure is an open creative process in the transversal of differences. Body-thinking can be experienced as well in the art of performance, as in dance and in other modes of a creative interacting with the world where body and mind are integrated.

Keywords: performance philosophy; dance studies; semiotics; body-thinking; democracy

\section{Prelude}

Democracy, born in ancient Greece in the fifth century BC, arose out of the enfranchisement ofan elite of free male citizens as a "rule of the people" in contrast to a government of an aristocratic elite. In the beginning, the definition of "free citizen" was restricted to a male elite. Therefore, it was the rule of a male citizen elite in contrast to the rule of an aristocratic elite. In modern times, in 1863, Abraham Lincoln defined democracy thus: "Democracy is the government of the people, by the people and for the people." In ancient and modern times, democratic citizenship was reserved to an elite class - until in the suffrage movements of the $19^{\text {th }}$ and $20^{\text {th }}$ centuries, democratic participation as full citizen was gained by all adult people. But still, it is not always clear who is in and who is out.

Participation in democratic processes is due to many factors. And even what is exactly the right definition of democracy is not clear. There is direct and representative democracy, or liquid democracy, which is a combination of them. Liberal democracy as a variant of representative democracy includes political pluralism, equality before law, due process, civil liberties, and human rights. The main pillars of democracy are freedom, human dignity, right to life, equality, minority rights, inclusiveness, right of speech, right of assembly, consent, voting, participation, and membership.

Democracy is the rule of the people, but it is not meant to be the "tyranny of the people", not "the tyranny of the majority". Therefore, Popper defines democracy in contrast to tyranny and dictatorship, emphasizing the importance and the opportunity for people to control and oust their leaders as basic to democracy (Popper, 2011).

Another intrinsic problem of the freedom of personal rights is the tension between democracy and the free market, between democracy and capitalism.

Referring to Giorgio Agamben, that tension was excluded in ancient Greek democracies, where in the antique world, pure natural life was excluded from the Polis as such. Rather, natural life was "as purely productive life restricted to the domain of the oikos." (Agamben, 2016, p.12)

Aristoteles in his ,Politics', makes the differentiation between 'oikonomos' and 'despotes' on the one hand, and 'politicos' on the other. 'Oikonomos' is the head of a household, who seeks to maintain the pure life of its members. In comparison, 'despotes' is the head, the leader of the family. Both are acting beyond the domain of politics. It is only the 'politicos' which acts like a citizen in the proper sense and only he is part of political society! This differentiation 
demarcates the pure fact of life 'to zen' against the politically qualified life 'to eu zen'. It was established for the sake of 'dear life', but it consisted for the sake of 'good life'. Aristoteles, as argues Agamben, defines the human being as 'politikon zoon'. That term is not an attribute to the living creature as such. Rather, it is a specific differentiation to define the category 'zoon'. Human politics differ from the one of animals by its faculty of speech. This means that the supplement of having the capacity of language makes of the policy of humans a community ofgood and bad, just/equitable and unjust/iniquitous. Throughout thousands of years, humans stayed as defined by Aristoteles, a living animal, with the capacity of a political existence. On the threshold of modernity, natural life gets integrated in politics. (Foucault, 1987). "The modern human being is an animal", as writes Foucault "where throughout politics his life as a living being is at stake". "The biopolitical threshold of modernity of a society is where the species and the individuum as simple living bodies are deployed by political strategy." (Foucault, 2006). The disciplinary force of the biopower generated "docile bodies". (Agamben, 2016). From here derive problems which can intrinsically endanger democracy. In The Will to Knowledge, (Foucault, 1987) Foucault argues that the evolution and the triumph of capitalism would not have beenpossible without disciplinary control over those docile bodies. To justify that control over the bodies, there had to remain a mode of thinking of general separation of body and mind in a Cartesian mode, like 'res extensa' and res cogitans" (Descartes, Meditationes). Nevertheless, human rights and freedom have a high political value, such bodyand-mind-separating Cartesian thinking culminate in a repression of bodies, of our bodies, making them into, as Foucault calls them, 'dispositive'2 of our interests, 'dispositive' of the interests of our minds. In a political context our bodies became objects of biopolitics. That can be seen in our worldwide desolate situation caused by over-rationalization, political and religious ideologies, racism, and gender injustice, which each in its mode are devaluating the respective 'other'. Symptoms are social injustice as well as the more than actual climate change. That is obvious in the fugitive wave caused by ideologic power-based war on the one hand and on the other hand by war and struggle for resources like fossil fuels, among others. And even the Corona pandemic can be discussed within this context. One important cause of the recent pandemic overcoming mankind may be that which Deleuze calls 'male white warrior' (Deleuze \& Guattari, 1980). An attitude to impose power against all that is different, not human,and not socialized as a white male western rational human being. That can be seen in the hubris and pride to explode and pollute our planet, to humiliate and maltreat animals as objects of our interests, to intrude and penetrate in the defense system of the earth, by destroying the rain forest and like that open 'Pandora 's box'. If we do not stop a thinking of separation of body and mind, of radical rationalization exploiting manpower, degrading non-human living species and after all, destroying the resources of our planet earth, we will not only devaluate, vulgarize and in that way dehumanize our living bodies and destroy the planet we are living on, but we may even risk human life on earth.

\footnotetext{
${ }^{2} \mathrm{~A}$, dispositive' in the sense of Foucault is always connected with power. 'Dispositive' are formed out of general discourses about different topics. They are the conclusion crystalized in a kind like 'matrix' which power uses strategically to impose on others for establishing certain objectives. (Foucault, 1978a, p. 119f)
} 
However, I do not want to open an unbridgeable gap of exclusion in the sense of bad humans vs. good nature, or bad rationality vs. good body. That would not only be naïve but would even transport the conflict into a never-ending hiatus. Rather, in my philosophy I would like to escape the accusing standpoint by analyzing the structure of the problem. And, if it succeeds, offering another mode of thinking-imagining-feeling, of coming in contact and responding to the other than us. Neither exclusive nor inclusive, but as an encounter in a transversal mode. 'Dancing bodies' might be a realm to open the gateway to such a new mode of encounter. In that concern I want to cite Lilach Livne, who I met at a conference on 'Dance Studies' (Coventry 2017): "I believe that choreography might have the potential to create new modes of philosophy, as well as new modes of being. By creating a sphere of co-imagining while resisting the control of the subject to transform into an image." I was impressed by the similarity of our ideas in certain areas. Nevertheless, I will not discuss her approach further in this study. I believe that the exploration of dancing bodies in their importance for democracy might be a good path to come closer to that purpose. Can dancing bodies be a pathway to freedom, to another mode of dialogue and to another mode of political and global thinking, which David C. Corten ${ }^{3}$ calls "The Great Turning: From Empire to Earth Community". The Great Turning is an "epic choice", a "Transformational Imperative". It is not a "prophecy", but a huge "possibility" to "reverse humanity's current course". "The ruthless domination and exploitation of Imperial Civilization have reached the limits of what the living system of earth and society can and will endure." We need a "transition to Ecological Civilization of peace, sufficiency, equality, and partnership for the well-being of all. Or we perish together in a final grand display of violence, excess, oppression and exploitation." (Corten, Yes! magazine, online, Home). Joanna Macy (1998) describes that transformational movement as "transformation from the industrial growth society to a life-sustainable society". She suggests three dimensions of change, first to slow down our current earth-damaging actions, second to analyze the structure of the problem and create a structure to achieve alternatives and third that we need "a fundamental shift in worldview and values" (Macy, 1998, p. 17). In his online article "Communication in the Age of the Great Turning', Farouk Y. Seif argues that "meaningful change" can only be attained by a "second order of change", which would be Macy's third dimension of change, a "cognitive shift" (Seif, 2007 , p. 3). He argues that we need "a shift in our perception and thinking process", if not "social and environmental problems will remain the same even though their appearance might change" (Seif, 2007, p. 3).

In this paper I want to research whether dancing bodies can contribute to that "cognitive shift" by exploring another mode of communication, another mode of thinking and interacting with the world. I have as my starting point one of the fundamental expressions of life, play, captured

\footnotetext{
${ }^{3}$ David C. Corten is part of the Earth Charter Initiative (2000). "The Earth Charter is a "declaration of universal responsibility to and for one another and Earth. It sets out four overarching principles of Earth Community: (1) respect and care for the community of life; (2) ecological integrity; (3) social and economic justice; and (4) democracy, non-violence, and peace."

4 “'first order of change' (fixes what already exists), whereas meaningful change is a 'second order of change' and is attained through cognitive shift." (Seif, 2007, p. 3)
} 
by the old German word 'Spil' , which means dance-movement. I want to analyze from bottom $u^{6}$, whether in the dancing of bodies there are hidden possibilities by using another mode of language, respectively entering in a pre-symbolic area of communication, andthus allowing fundamental, life-changing, and society-changing possibilities to develop. Bodies have first to regain their autonomy or at least, get an idea and get conscious about what is happening with them and thus become increasingly aware of disciplinary structures and prefixed, prejudiced images acquired. Because, according to Foucault, one causal reason of Imperialistic and Capitalistic expansion is the disciplination of living bodies. To realise a possible shift in our thinking there must be attaint first some mode or possibility of liberation of fixed and determining structures in bodies. Those structures are woven in symbols that are imprinting our bodies preconsciously. Are dancing bodies able to go beyond symbols and so deconstruct power relations? In other words, do they have access to a mode even before symbols are created! In society those power relations are embedded as 'imprints' of structures. Those 'imprints' become a social reality and are unconsciously embedded as supposed a priori images we pose on living bodies. Here in my opinion, problems derive which not only can intrinsically jeopardize democracy, but also put at risk our entire acting in the world!

In that paper I want to research whether dancing bodies can be a realm to have access to that other mode of thinking - which means amplifying our capacity of thinking to a wider range of imaginative possibilities and therefore getting access to another mode of consciousness.

\section{Method}

My method of research is based on the task of figuring out another mode of thinking by examining another mode of the use of language. As Farouk Y. Seif argues about the "Paradox of Language" (Shlain, 1991, p.18) in his article 'Communication in the Age of the Great Turning' (Seif, 2007, p. 5), language on the one hand offers the resources to think abstractly, but on the other hand we seem to "abandon the use of images and are able to carry on without restoring to them"(Shlain, 1991, p. 18). Seif argues that imagination is as well a sort of abstraction, but "Since imagination involves more than logical, linear operations and depends on the acquisition, interpretation and manipulation of images and nonverbal codes, it does not fit neatly into the mainstream, conservative understanding of abstract thinking." He calls it the "AnalogDigital Polarity." (Seif, 2007, p. 5). To be more conscious about our use of language he suggests "to revisit and locate language within a larger scope of semiotics" (Seif, 2007, p. 5).

In my research I will try to find access to that problem by revisiting semiotics in relation to dancing bodies. My perspective to that task comes on the one hand from bottom up and derives

\footnotetext{
5 "Playing is a type of free action, but you lose a part of your autonomy as well, because you do not exactly know how the play will end. You have to let yourself be involved in another state of mind. Playfulness is central in the art of performance. Games are fictive constructions, but at the same time, they constitute an exchange and interaction, and produce social and cultural realities." (Baumgartner, Meyer-Dinkgräfe, 2019, p. 519)

6 "Through bottom-up processing we detect the lines, angles, and colors because the processing begins with our sense receptors. (Myers, 2007) On the other hand, through top-down processing we consider our knowledge such as the painting's title as our experience and expectations are the components operating the processing." (Myers, 2007)
} 
from my professional experience with dancing bodies, in which I recognized some basic categories of Charles Sanders Peirce's semiotics. Those are the categories of three, as quality of feelings, impulse and resistance, and structure, which are called the categories of firstness, secondness and thirdness. My analysis is in analogy to those categories. On the other hand, from top down I will give a theoretical review of Peirce's semiotics. In reference to my dancephilosophical approach I will subject those categories to critical research - especially the mode of thirdness, with a critical view to the final interpretant. Here lies the possibility carving out another mode of thinking, whose structure is more open to a free simultaneous vision of equal, multiple possibilities. In addition, by a composition mode I call frottage, there might be the possibility to deconstruct rigid structures and open a free vision of "simultaneously capturing whole and infinite imaginative possibilities" like Farouk Y. Seif (2007) mentions by the analogue mode of thinking. In this way, body-thinking might be established as a special mode of communication.

\subsection{Pre-semiotic approach of body-thinking}

\subsubsection{Bottom-up perspective}

In my work as a philosopher, choreographer, dancer, and pedagogue, I started to explore the possibility of other modes of thinking, of experiencing and understanding the world, more holistic ones, in which body and mind are integrated and constantly interacting with the surroundings. By surroundings I mean all that is other than us. That development related with my biography of being both, philosopher, and dancer, guided me to develop 'body-thinking'. Hereby my work with living bodies in my dance and movement classes as well as in my performances were the research field. In my performances I experimented with a variety of different art forms, trying to keep every participant's own value. I found out that by interacting in a non-authorial and non-hierarchical mode, something new, unexpected was created. Those new creations came out of melting processes in which borders from one to the other opened. The organization principle was a specific arrangement of different layers. It was a contemporaneous overlay and interaction of different art forms happening in a playful mode, in a mode of a creative interplay.There was a friction between the different layers, which I called a frottage of diversities. The term frottage is not my invention. Rather, frottage derives from an old tracing technique and means interacting by rubbing with a pen the surface of a material placed underneath, so that the traces of the one below will appear on the other canvas. However, it is not an exact copy, no faithful reproduction, but an influence from one to another, where the result is some new creation. Literally it also has a sexual connotation. In 1925, Max Ernst used this old tracing technique to develop his own artistic style.

I use 'Frottage' as a performance practice of simultaneity, contemporaneity, and non-linearity of different layers. In contrast with a collage, it is a contemporaneous overlay of different layers as dance, video, pictures, words, of different meanings or different philosophical perspectives. Hereby the bodily element of rubbing one against another to create new combinations is included. There is an impulse, which meets a resistance and in a merging process, new creations come to birth. In the creative process of my performances one can recognize a mode of three as quality of feelings, impulse and resistance, and structure, which is quite like 
the semiotic process that Charles Sanders Peirce describes in his semiotic philosophy. In this way, my performances have taken on a philosophical direction - not only because they address philosophical topics. Rather, the structure I developed throughout the mode of creating as an interlaced reflection of different media and layers, of different art forms, is genuinely philosophical. It stands in a living relation to the semiotic categories of C. S. Peirce. In my paper I demonstrate why. Considering that, I will first provide a brief overview of the philosophy of C.S. Peirce as relevant to my argument.

\subsubsection{J. S. Peirce's semiotics -Top-down perspective}

Charles Sanders Peirce was an American Pragmatist. For Peirce, the common, broad, and overall experience of human perceiving is the point of departure of all philosophy. He formulated the fundamental relation of thinking and reality. It is not the scientific description of the world but the instantaneous experience which is the foundation of all philosophy and science. However, that would not distinguish the philosophy of Peirce from any classical or logical empiricism. Peirce agrees with Kant that the mode of how we perceive the world is the base of our experience. He tried to strengthen the categories of Kant, which he thought were not concrete enough, to arrive at fundamental structures being the base of our thinking.

In general, the concept of relationship and mediation gets an important emphasis in Peirce's thinking. For him, all thinking is thinking in signs, which are mediated by different structures of relations. Those structures are Firstness, Secondness and Thirdness.

"Firstness is the mode of being of that which is such as it is, positively and without reference to anything else.

Secondness is the mode of being of that which is such as it is, with respect to a second but regardless of any third.

Thirdness is the mode of being of that which is such as it is, in bringing a second and third into relation to each other." (Peirce, 1904)

Each category of firstness, secondness and thirdness is as well divided in three. Out of the calculated combinations of those $3 \times 3 \times 3$ result 27 combinations of which only 10 trichotomies can be applicated. The application must always combine all three parts of a sign descending from the interpretant.

Peirce's starting point is the immediate experience; that experience is mediated by those fundamental categories of relationship between impulses and resistances. Here, subjective intentions striking an independent object are experienced as a resistance for the intentions of a subject. In a continuous experience a certain regularity of relations of impulses and resistances may be noticed. This mediating third, noticing a possible regularity in the experience of the relation of firstness and secondness is called the interpretant of that mediating process, 
and it takes the level of thirdness. The instantaneous experience for Peirce is not the individual experience, but an undivided impression of consciousness. He calls it Phaneron ${ }^{7}$.

Peirce's categories - technical name: the cenopythagorean categories:

\begin{tabular}{|l|l|l|l|l|l|l|}
\hline Name: & $\begin{array}{l}\text { Typical } \\
\text { Characterization: }\end{array}$ & $\begin{array}{l}\text { As Universe } \\
\text { of experience: }\end{array}$ & As Quantity: & As Modality: & $\begin{array}{l}\text { Technical } \\
\text { Definition: }\end{array}$ & $\begin{array}{l}\text { Valence: } \\
\text { "adicity" }\end{array}$ \\
\hline Firstness & $\begin{array}{l}\text { Quality of } \\
\text { feeling }\end{array}$ & $\begin{array}{l}\text { Idea, chance, } \\
\text { possibility }\end{array}$ & $\begin{array}{l}\text { Vagueness, } \\
\text { "some" }\end{array}$ & Possibility & $\begin{array}{l}\text { Reference to a ground } \\
\text { (a ground is a pure } \\
\text { abstraction of quality) }\end{array}$ & $\begin{array}{l}\text { Essentially monadic } \\
\text { the quale, in thesense } \\
\text { has the qua-lity) }\end{array}$ \\
\hline Secondness & $\begin{array}{l}\text { Reaction, } \\
\text { resistance, } \\
\text { (dyadic) relation }\end{array}$ & $\begin{array}{l}\text { Brute facts, } \\
\text { actuality }\end{array}$ & $\begin{array}{l}\text { Singularity, } \\
\text { discreteness, } \\
\text { "this" }\end{array}$ & $\begin{array}{l}\text { (contingent) } \\
\text { Actuality }\end{array}$ & $\begin{array}{l}\text { Reference to a corre- } \\
\text { late (by its' relate) }\end{array}$ & $\begin{array}{l}\text { Essentially dyadic(the } \\
\text { relate and the corre- } \\
\text { late) }\end{array}$ \\
\hline Thirdness & $\begin{array}{l}\text { Representation, } \\
\text { mediation }\end{array}$ & $\begin{array}{l}\text { Habits, laws, } \\
\text { necessity }\end{array}$ & $\begin{array}{l}\text { Generality, } \\
\text { continuity, } \\
\text {,all“ }\end{array}$ & Necessity & $\begin{array}{l}\text { Reference to an } \\
\text { interpretant }\end{array}$ & $\begin{array}{l}\text { Essentially triadic } \\
\text { (sign, object, interpret } \\
\text { ant) }\end{array}$ \\
\hline
\end{tabular}

(Source: Peirce's ON A NEW LIST OF CATEGORIES [Cooper, 2008])

Complete table of Peirce' categories constituting a sign:

\begin{tabular}{llll}
\hline $\begin{array}{l}\text { REPRESENTA- } \\
\text { TION }\end{array}$ & $\begin{array}{l}\text { RELATION TO } \\
\text { THE SIGN }\end{array}$ & $\begin{array}{l}\text { RELATION TO } \\
\text { THE OBJECT }\end{array}$ & $\begin{array}{l}\text { RELATION TO } \\
\text { THE INTERPRETANT }\end{array}$ \\
\hline FIRSTNESS & SECONDNESS & THIRDNESS \\
\hline FIRSTNESS & QUALISIGN & ICON & RHEMA \\
SECONDNESS & SINSIGN & INDEX & DICISIGN \\
THIRDNESS & LEGISIGN & SYMBOL & ARGUMENT \\
\hline
\end{tabular}

For Peirce, the primary task of philosophy was to discover the general and formal determinants of thinking and experience - however, on the bedrock of critical common sense. The function of Peirce's "Critical Common sensism" is the thesis of sensual disclosedness before any kind of theory (Pape, 2000, p. 30).

The base of all philosophy for Peirce is first Phenomenology and then Mathematics. From both derive Semiotics as a philosophical discipline as the logic of signs and then all other philosophical disciplines follow as subordinated.

\footnotetext{
7 "I propose the word Phaneron as the proper name to denote the total content of any one consciousness (for anyone is substantially any other), the sum of all we have in mind in any way whatever, regardless of its cognitive value. This is pretty vague: I intentionally leave it so." (Peirce, 1893-1913, p. 362).
} 
In the typology of the three, the sign is understood as a structural element of inference. "A sign is a likeness; and this is the main mode of representation in all art" (Peirce, 1867-1893, p.282). Here all moments of the triadic relation refer in such mode to each other that the higher position implies the former, but not vice versa, the lower the higher (Schönrich, 1990, p. 104/105). "A sign is a third mediating between the mind addressed and the object represented" (Peirce, 1867-1893, p. 281). Namely in the mode of a likeness to bring together the dynamic object, "as it really is on which the immediate object is founded as "on bedrock" (Peirce, 1867-1893, p. 282). The interpretational process is a continuum. However, to guarantee the continuation of this interpretational process, so that it does not lead to a never-ending chain of interpretations, Peirce had to propose a final vision, as a framing category. Sign and object must be equivalent in the long run to guarantee the entire possibility of the interpretation of the object. Dynamic object and immediate object will have to be brought together! In the long run, the sign as the representation of the object will coincide entirely with the object. This future vision as the end of the interpretation process is called final interpretant. The final interpretant "would be reached if a process of enriching the interpretant through scientific enquiry were to proceed indefinitely. It incorporates a complete and true conception of the objects of the sign; it is the interpretant we should all agree on in the long run" (Hookway, 1985, p. 139). Therefore, to reach an entire interpretation of the object of a sign, Peirce needs a final interpretant. Peirce's Pragmaticism emphasizes that reliable knowledge can be reached neither through instantaneous intuition, nor through contemplation or speculative phantasy. Rather, it is achievable only by practical and theoretical, operational processes. Those processes need a huge scope of experimental freedom on the base of a special power of judgement he calls Abduction. Abduction is the invention of a rule and its projection in the long run, which yet does not exist (=Firstness). Deduction (=Secondness) deduces the consequences of it, the applications, and Induction (=Thirdness) examines and confirms the rule.

\section{Analysis of Body-thinking: examining the specific pre-symbolic structure of dancing bodies (and its impulses for democracy)}

In the following I analyze the pre-symbolic structure of the dancing of bodies, which on the one hand gives access to another mode of thinking and another use of consciousness and on the other hand provides impulses for democracy. By mentioning the body as a living entity with its own structure-revealing power, and so as ensue that the body is not considered the same as reason, but that the body has its own mode of intelligence, I analyze my dance performance in analogy to the categories of C.S. Peirce, having as well phenomenology, the immediate experience as primary point of departure - because the knowledge gained from that process will not be a representation of an object by a sign, but its presentation in a singular moment as a 'Performanz' (Baumgartner \& Meyer-Dinkgräfe in Williamson \& Sellers-Young (ed), 2019, p. 513), Performanz as I mention it here is an immediate transmission of an understanding in a singular moment, which gives emphasis to another mode of understanding through a realtime experience capturing the whole of the instant moment, before it gets fixed in categories of terms. 


\subsection{Contact improvisation}

In the first scene one can see the dancers activating their energy pathways by Daoist Taiji movement practice, so that they are moved no more by the intentionality of their brains. Rather, the movement impulses are caused by feeling the flow, the motion of the blood stream, the vibration of the cells, the breathing. Like this, they primarily focus on a sort of 'body-intentionality $^{8}$, in analogy to the phenomenology of Evan Thompson (Thompson, 2007, p. 22). In Peirce's semiotic terminology that would be a state of firstness, as possibility, as feelings and vague images, unstructured ideas, arising by chance. It is an aware but quite unconscious state of mind. Here the object relation is still completely undetermined. Any relation to any kind of object could be possible. The mode of firstness concerning the relation of structure, called rhematic relation, only provides possibilities under which an object could be represented, but without determining an actual structure of object relation. This is a kind of primal semiotic condition. The semiotic mode of bodies here are quali signs (firstness of firstness) with iconic (firstness of secondness) relation to the object and a rhematic (firstness of thirdness) interpretant, providing the mode of structure. Iconic relation to the object means it is indeterminate which object is meant. The intentionality of the dancers is not focused, all and everything could be meant. One could say, in contact with the other dancers, the dancers give up their will of making a movement. Rather, they are moved and are moving in relation to the other. However, signs in the pure mode of firstness and thirdness do not exist as such. They always must be embodied in the mode of secondness. There happens instantiation of signs, called Performanz as embodiment. Therefore, moving actually on stage, in the semiotic terminology of Peirce one has to say that bodies are embodied as sin signs (secondness of firstness). Bodies get instantiated as sin signs, in a mode of existence, with iconic relation to the object and rhematic relation to the interpretant. However, concerning the mode of firstness, a qualisign, as firstness of firstness, which means the non-embodied aspect of the sign, must be exemplified. Performanz as exemplification is a relation that always joins Performanz as embodiment and interferes with it. Here the sign relation is reverted, which means it represents not from the sign to the object, rather from the object back to the sign. In the performance that can be realized either by the dancer's feelings or by the spectators abstracting from the embodied mode of existence a mode of firstness as quali sign. But, only in relation to a resistance, to an object, all qualia and structures reach a mode of existence, as embodiment. Embodiment is the mode of secondness. It is felt as resistance from an object, as the other thanI, where impulses can arise out of that. It is a dyadic relation based on resistance and reaction, a state of actuality, a correlation of brute facts realized in a discrete special moment. However, performing a resistance as secondness with a highly activated state of firstness, the focus is notso much on the brute resistance, but on the flow of feelings, impulses, and so on impressions created out of that dyadic relation. For each of them the state of firstness is the focus, even if resistance is felt as concrete reality. In that mode, resistance is not felt as an obstacle, as a brute fact of otherness. Rather, here it can be experimented as a backing resistance, supporting each one's weight.

\footnotetext{
${ }^{8}$ In the 2. chapter of his book Mind in Life, Evan Thompson explains different modes of Intentionality concerning phenomenology. "According to phenomenology, consciousness is intentional, in the sense that it "aims toward" or "intends" something beyond itself." (Thompson, 2007, p. 22) That means a definition in a wider sense for consciousness to be open towards "the world or what is "other" ("alterity")" (ibid). The narrower sense of intentionality in Phenomenology is "object-directedness" (ibid).
} 
Thus, in contact improvisation, a connection is created, a common centerline between the I and the Other. Furthermore, there might arise the sensation of becoming one unique body. However, the awareness of each physical force and weight transfer is important. It is like a changing play in holding and resisting each other with a higher state of awareness. In analogy to Peirce, one could say: it is a play of embodiment in the mode of a secondness witha highly activated state of firstness. The revealing, enlightening, and disclosing experience of it is the following: if one subject were to dissolve, the common axis would break down and the contact improvisation, this improvised playful dance, as a unique body consisting of several bodies, would not be possible. Concerning a possible connection of body-movements and democracy, that experience is one indication that a decision for a functioning community is not only based on a rational decision by arguments and rules. Rather, harmonic interaction can arise as well out of body-communication: body-communication as a new feeling of deep connectedness with the other might open another access to the other in the mode of solidarity and fellowship. And therefore, open an access to an open community. Concerning the nexus, the correlation with the categories of three, all other states are immediately activated - however, with main emphasis on particulars. So, if the focus is on firstness, the resistance changes in both dancers in a smooth mode. And as firstness is not yet the differentiation of an object, in the contact of both throughout the main state of the quality, feelings have no limit and can smoothly flow and cross over the borders from one to the other. That would be a kind of anastomosis of the subjects.

In relation to the performed resistance belonging to the state of secondness, the impression of the other as object is constantly shifting between immediate and dynamic object. It is a blurring, a shivering sensation between the other as 'image' and - to use a Kantian term - 'thing in itself' ${ }^{9}$ (Kant, 1787, KrV, B 164), which means as the living entity it 'really' is. Throughout rational thinking, the 'thing in itself' can never be reached as it is. All we can gain through terms is its representation. In contrast to thinking in terms, here the sensation of being oneself or the other is blurred. In that mode, objects seem to give access to what they really are. Further, one might realize a kind of subject-object-ness, a sensation of open borders in which something new happens, as a melting process of being one and different at the same time. It is like a kind of orgasm, where the borders of the I open to the other. However, for not getting lost in that blurring sensation, rather, for not to fall or hurt oneself, both moving bodies must stay in a state of high awareness to play with each-other's resistances. Imprints of feelings, images and ideas will stay as an amalgam of one's own and those received from the others, as imprints, as remnants, vestiges, remaining of the common experience of dancing with body-weight transfer. All of this happens in the mode of secondness, but in a singular present moment.

\footnotetext{
${ }^{9}$ The term , Thing in itself '- 'Ding an sich', Kant used more than 100 times in his writings and it has several meanings. Here I refer to the meaning of empirical standpoint, which means the real object as a positivistic, undoubted, and unquestionable being of things. "Dingen an sich selbst würde ihre Gesetzmäßigkeit notwendig, auch außer einem Verstande, der sie erkennt, zukommen. (KrV B 164)
} 


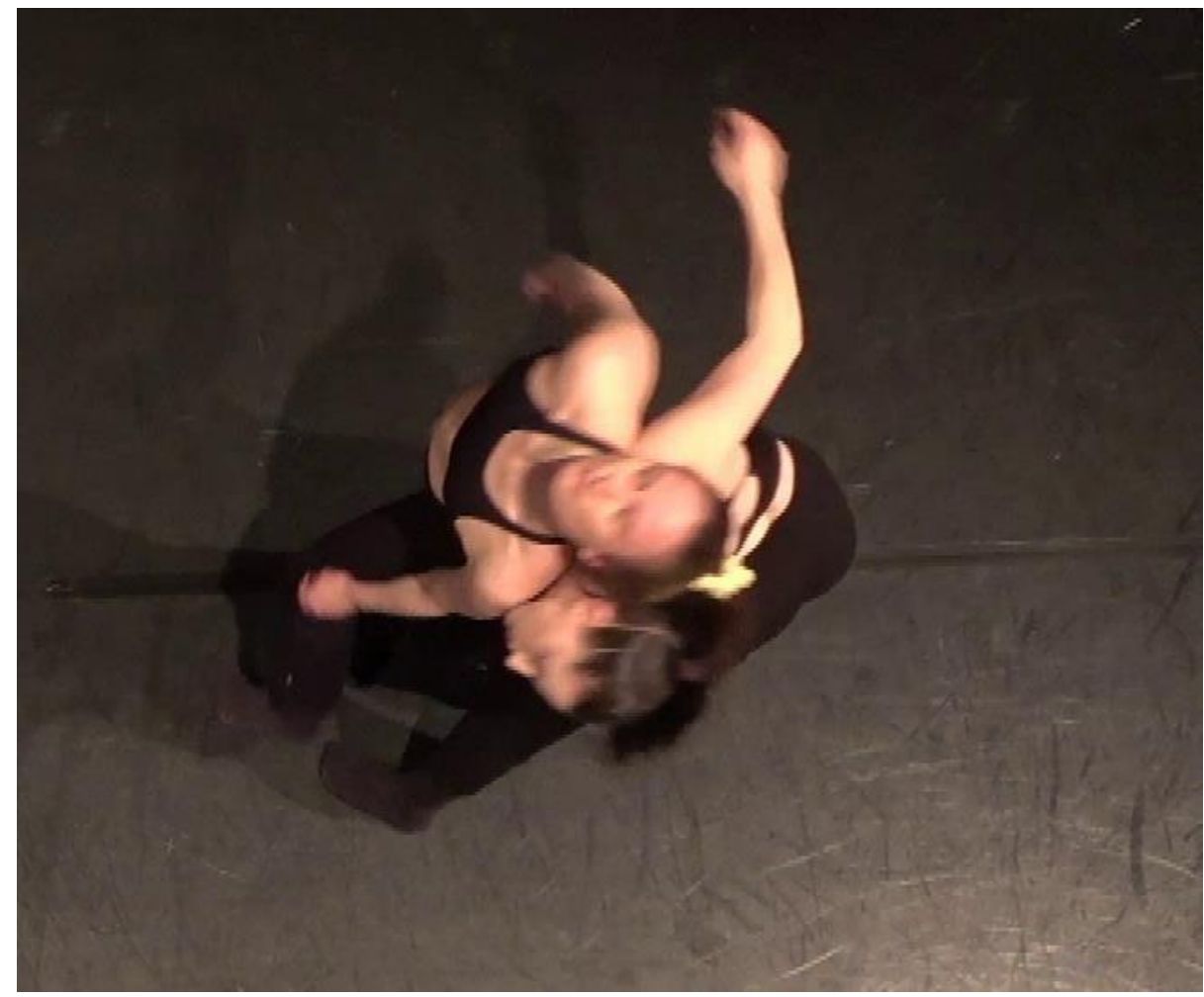

Raphaela Baumgartner and Karoline Ruf in 'Dancing bodies as impulses for Democracy'. Photo: Aurelia Baumgartner

So, there will be one first important conclusion: in the interaction of different bodies, of different subjects in dance by contact improvisation or in performance art by the frottage of differences, something new is created as a 'Performanz' (Baumgartner \& Meyer-Dinkgräfe, 2019, p. 513). It is happening as Performanz in the semiotic meaning of embodiment and exemplification, but it embodies like a signature, being a true expression of oneself, and here a true expression of subject-object, with impact on reality. It happens in a singular present moment and is based on weight transfer, an impulse that meets a resistance, a rubbing process in which the subjects are becoming porous. That is what I call a frottage. This happens by interlocking, by permeability and transitions of the different subjects, which is a 'trans' passing, transcending to the other. At the same time, this process is a crossing the borders to the other and in the other way turning back to oneself, with impulses and resistances coming from one another. This is a 'trans' 'vertere' in the Latin sense of crossing borders as 'trans', and 'vertere' as to reverse, to turn something inside out, to invert, to turn around, to refer back to something. This I call a transversal (Baumgartner \& Meyer-Dinkgräfe, 2019, p. 517, 518). It means that something is happening even inside the subject and inside the 'object'. In this transversal the subject becomes porous, is sensitive, vulnerable, and receptive to the other. The subject becomes other, but without losing itself, however, by transforming itself without absolutely dissolving its borders but by crossing its borders onto the other, to give birth to another becoming. 
Here even the sensation of the object as resistance, as representation is decamped, is soaked. So, one can conclude that on the one hand, the immediate and the dynamic object are in a blurring relation. The immediate object is losing its rough category as pure representation and the dynamic object is opening itsineluctable state as thing in itself, because the glimpses of its unique living reality are unveiled. That does not only matter for the categories, the structural elements. It counts for the dancers as subjects as well. Therefore, in contact improvisation each gives up its dominance, its rule assault as an absolute subject, to create a common axis, a common force, as different subjects with one core center. In this empathic sensing feeling interaction, in this other becoming, the subject is becoming other and gives birth to a humble subject, to a transversal subject (Baumgartner \& Meyer-Dinkgräfe, 2019, p. 518).

Hereby the interaction of the dancers is becoming a mode of playing with their intentionality's instead of following a logical order. That communication is pre-rational. One can interpret it with semiotic categories, but in the mode of openness to results. There is no possibility of repetition of exactly the same subject-object interaction. And so, no finalization. There is a semiosis without a final goal, without a final structure. Therefore, a semiosis without final interpretant. That semiosis happens even before signs are created. Freedom, transversal freedom, or freedom resulting from a transversal, transcends out of that mode of subject-object interaction, which is a creation of a momentaneous, spontaneous state of 'subject-object-ness'. It is a new mode of communication, which I call a third language (Baumgartner \& MeyerDinkgräfe, 2019, pp. 519-521)..

\subsection{Power-Games, 'Will to Power'}

However, there are other possible modes of bodily interaction. The second scene shows a sort of struggle because of strict subject-object separation. Each subject tries to impose its movement flow onto the other. Herby the other is treated as object of manipulation. If the state of secondness were felt as brute fact, the state of subject-object-ness would be hard to reach, there might be some moments of transversal, but both, subject and object would radically be separated.

In Peirce's terminology the moving bodies are sin signs with indexical relation to an object interpreted in a dicentical mode. A dici sign is a fixed statement, which each dancer claims for its own. The body of the other is fixed as concrete otherness, as completely separated from oneself. So, power games will arise. All signs are only moving on the axis of secondness. They represent what they are: moving bodies, bumping into each other. No quality, no mode of firstness can be abstracted, no thirdness will be instantiated! Bodies claim power as rough weight transfer, oppressing the other. Therefore, feelings are thrown back and will be retained in each subject as rejected impulses. The emotion of fear will arise, and the subject's borders will be closed. A rough duality can be felt, which spirals into conflict. It would be the Hobbesian primitive political condition of 'homo homini lupus est', long before any social contract.

Concerning dance productions, not all choreographers allow that self-opening process of transversal interaction. Rather, due to the authority of a choreographer or, on the other hand, due to the ego of the dancers, there are often power games, in which the most skillful imposes his will to the others. However, power relations are not only destructive. They are installed in each 
organization and institution to distribute roles for the whole structure to work. In that structure a souverain is necessary to guarantee the freedom and functioning of an organization or of a state. In political theory one finds a lot of different modes of causing the installation of a souverain. Different forms of government will result from this. Within the constraints of this article, I cannot discuss them further. As explained above, the state of secondness is characterized as rough dyadic relation. The focus on secondness here is the state of an austere actuality of brute facts. It is effectuated in a dicentical structure, as fixed statement. The consequence of that state of secondness is always division, separation - subject-object separation, as it were. In the performance the mode of secondness and its rough consequences are experimented as a fight, as struggle one against the other. During the performance, each dancer could feel the useless effort to impose one's own will onto the other, which when realized until to its limit leads to struggle and destruction of any dancing together. There will be no dance anymore. It would be a self- destruction of the dance, and so a destruction of each self's intentionality, of each one's freedom, included the possibility to reach 'transversal freedom'!

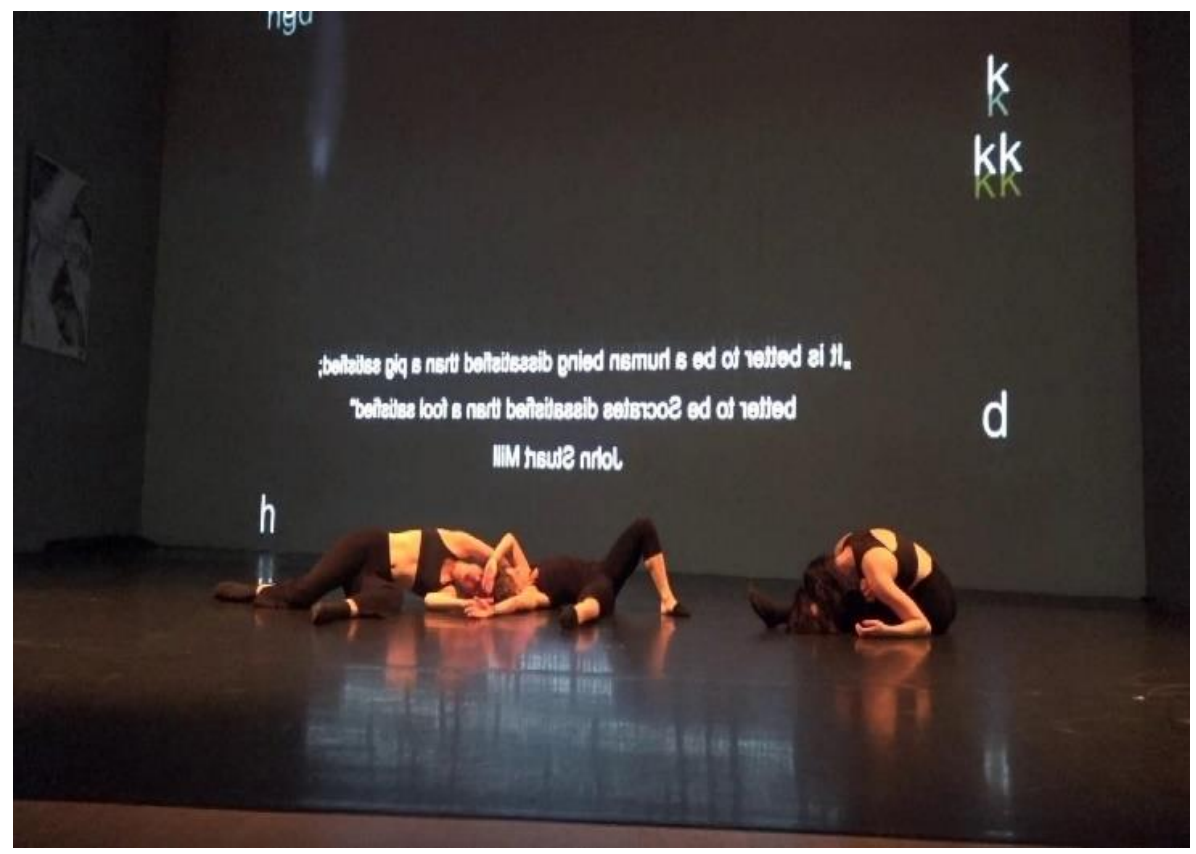

Raphaela Baumgartner, Ina Bures, Karoline Ruf in 'Dancing bodies as impulses for Democracy'. Photo: Aurelia Baumgartner

Repetition of the repetition may be the key to deconstruct the rough duality, realized in the performance by the dancers both in presenting and exaggerating them. Hereby, those power games get an ironical connotation, and the possibility of their deconstruction arises. 


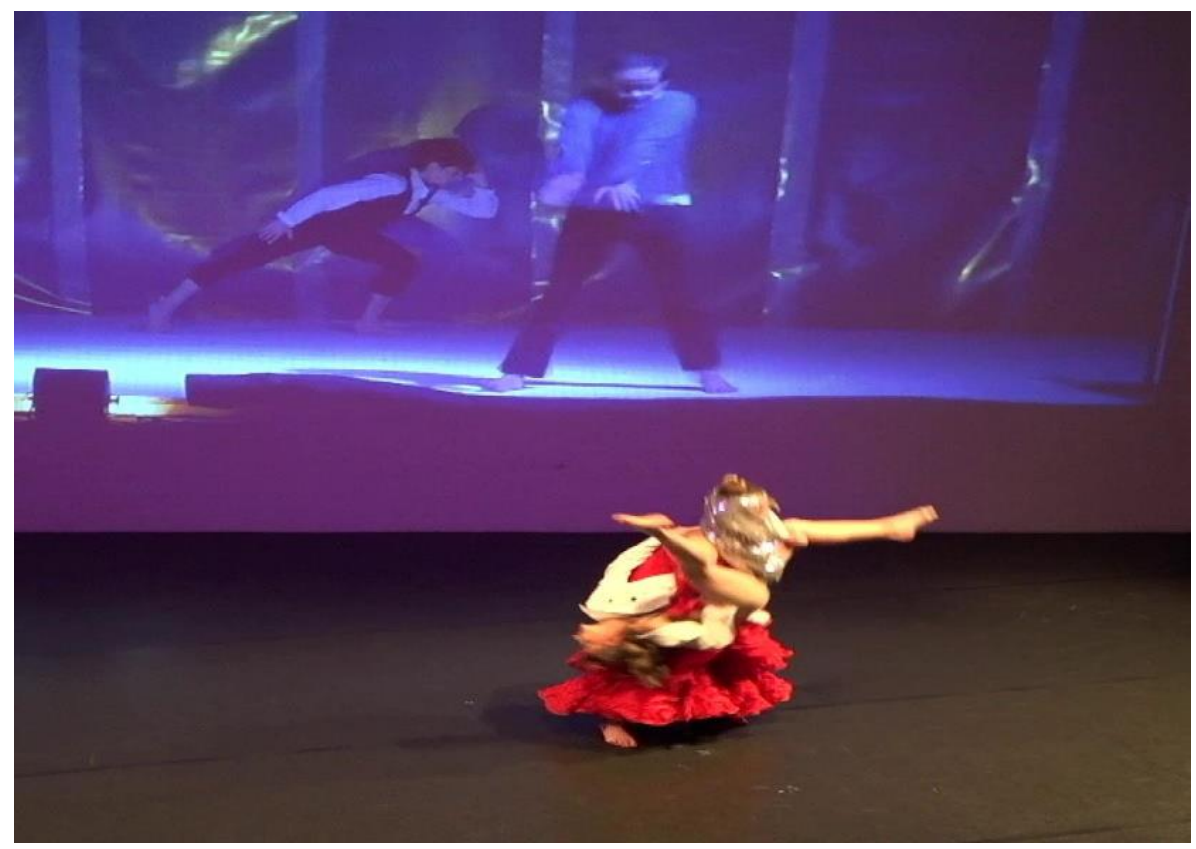

Ina Bures, Raphaela Baumgartner, Vincenzo Lapertosa in 'Dancing Bodies as impulses for Democracy’. Photo: Aurelia Baumgartner

Irony was still a movement towards distancing oneself from a rough fact. As developed in the period of Romanticism as ,romantic irony', in current linguistics it indicates the gap between what is happening and its meaning, by exaggeration. From this, a movement of alienation results, in which one has the possibility of getting a critical distance for reflecting one's own standpoint.

In reference to the semiotics of Peirce, continuous repetition of the semiotic triangle leads to a reflected state of thirdness.

\subsection{Structure vs. Freedom}

The state of thirdness is like the other categories of firstness and secondness, divided in three. 'The firstness of thirdness is a 'rhema'. It means only the aspect as possibility, under which structure an object relation could be instantiated. That relation offers possibilities under which an object can be represented, but without specifying a certain object to be represented. All might be possible. It is a primal semiotic condition in the state of thirdness. The secondness of the thirdnessis a 'dici-sign', which I explained above as fixed statement. The thirdness of the thirdness is an'argument'. It is not meant in a narrow sense of a logical argument. Rather, it is a kind of 'symphony' of all assignments of an object realized in a semiotic process. However, as explained before the state of thirdness as such does not exist. It can only be embodied and therefore come into existence in a mode of secondness. 
Concerning the Transversal realized in the performance, thirdness is a certain kind of regularity in the mode of secondness of the bodies meeting each other. That would be a regularity of the rule-lessness, where bodies trans-vert and transform to a mode of subject-object-ness.

Concerning Deconstruction, the deconstructive power of the repetition of symbols, it wouldbe the following: Thirdness of secondness is called symbol. Symbols are embodied on the axis of secondness. They are images on bodies in which there is a reflected relation between the 'object as it really is', the dynamic object, and the meaning transporting part of the object the immediate object. Between immediate and dynamic object there is a dyadic relation resulting as a reflected picture, as an image transporting a meaning. Here lies the possibility to deconstruct images frozen in symbols. The deconstruction lies in the differing of immediate and dynamic object of the symbol realized by the constant repetition of the constituting process of the creation of that symbol.

Repetition has two ways:

1. With the goal as final interpretant, former states in the repetition will aim at a fixed idea that the immediate and dynamic object of the symbol will fall together; this means that they will be the same in the end of time. To achieve continuous repetition, in the triadic relation of firstness, secondness and thirdness, firstness and thirdness are constantly changing place, to enrich the symbolization of the dynamic object throughout the immediate object. Like that, what has become a structure in a semiosis and therefore stands at the level of thirdness, will be the impulse for the next semiosis, to be able to specify the object increasingly. That specification takes place at the immediate object, which increasingly defines the dynamic object in all its aspects.To stop a never-ending chain of increasing semiosis, that process must take place in a continuum of time with the aim to reach a final interpretation. However, because of the time continuum, in every continuous repetition, the symbol of the immediate object will be increasingly fixed to reach that sameness with the dynamic object. In consequence, there is a teleological, unifying movement towards a state of the end of interpretation. Peirce calls that rule-finding process Abduction.

2. With giving up the idea of a final interpretant, the immediate and the dynamic object of the symbol continue to vary. They differ because there is no final idea of what the immediate object of the symbol must become in the end of time. Therefore, in that mode of secondness of thirdness there is an emphasis on continuous resistance between immediate and dynamic object of the symbol. That can be interpreted as a constant play with pictures resulting from the resistance of the dynamic object, which now is not oppressed under a telos in becoming any fixed symbol. Rather, with the fixed borders of time as continuum, and of space, loosened, the dynamic object of the symbol is released from enforced constraints to linearity and continuity. It stays as it is, in its suchness, and is involved in a semiotic process of contemporaneous overlay of changing time and space. The immediate object is released from an enforced telos of continuously fixing symbolization under constraint of the rule-finding process of the Abduction to reach a final interpretation. That initiates a reflective power of imagination to play with different modes of symbolization of the same picture. Therefore, the symbolization has the possibility to change. One could find an analogy to this mode in Kant's free play of imagination and reason in the esthetic judgement (Kant, 1790, KdU, 1.part). Such free interplay of imagination and reason is based on the pure reflecting power of judgement, without subsuming the 
images of imagination under whatever invented rule. That mode differs from Peirce's Abduction. In the reflecting power of judgement in the Kantian mode of the esthetic judgement, the free power of imagination is in constant play with the rule-assaulting intention of reason. In Peirce's semiotic terminology one can call it a pre-symbolic process. It is a constant free play and interchange in what a dynamic object is and might be, during its symbolization as an immediate object. Hereby, change has become an important part of any symbolization.

In my performance the following part is based on figuring out the possibility for change. The structure in its repetition is not only the basis for the creation of a rule, in the mode of an argument. Rather, inherent is the possibility for change. To get to that point there must be a creation by impulses and resistances released from a teleological goal, released from the necessity of continuity in time and space. However, not without any kind of structure and not without reflection. Reflection here is inherent to the symbolization process, as constant 'play' of symbols as immediate object with the resistance of constantly changing symbols due to the dynamic object - without goal of finalization in a fixed rule. Therefore, the possibility of rulefinding lies open and remains creative. As such, there will be no final 'sovereign', no 'final interpretant.' Therefore, freedom as well as 'transversal freedom' will be possible!

It happens the following way: without the goal, the telos of a final interpretant, one can realize the dissolving of the strictness and rigidity of a linearity resulting from a prefixed time and space order. In the performance a structure released from the exact focusing on space and from exact timing as counts, as well as faults entering the structure, opens that rigidity.

That mode without final interpretant even enriches the choreography. Because there is an overlay of different moments in time and therefore a variety in which dance can happen. And although the space may be the same, there is a free choice of the directions.

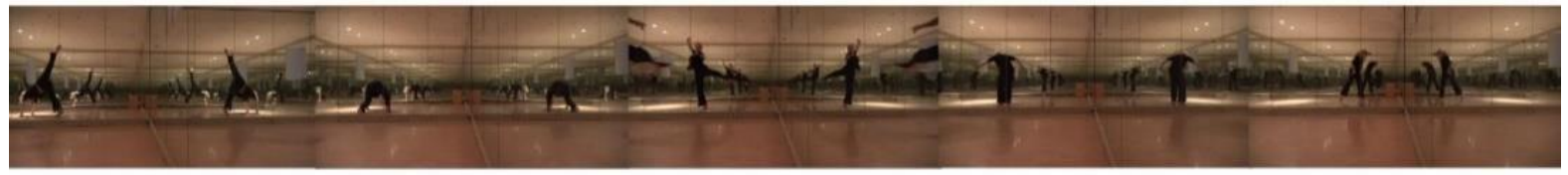

A structure as a thirdness and therefore a sign is created by repeating the semiotic triangle. However, in the mode of no final interpretant, there is a constant play of immediate and $d y$ namic object in the symbolization process. It is a pre-symbolic process.

In contrast, to reach the correct vision of the object, the immediate object must fall together with the dynamic object in the end of time. However, to reach that, a continuum of time and space would be necessary. Rather, in the dynamic state of lived reality, a continuum is only a heuristic idea under which life must be subsumed. That is not possible, even if one thinks to have finally reached the full meaning of a term, or to have formed a concept, an argument. The living entity of the body is constantly changing. Further, in a semiosis the state of firstness is defined by contingency, potentiality. Feelings, possibilities are guided by chance. In the context of life, one cannot repeat exactly the same structure. So, in analogy to that, by continuously trying to repeat the same structure in dance, one can recognize that small errors have crept in 
during the process of repetition. Those mistakes, however, can break up the rule and make a change. And not only the mistakes, even the release of exact timing and space order, as well as changing times of performing have the same consequences. It is even so with thinking the same thought at different moments in time, with different foci in space. Concerning a rational argumentation in a lecture: the lecture is always delivered by a living being, an argument in a text is always read or performed by a living being. It is a performance: a unique moment in time and space performed by a living subject with its unique focus. The same happens with all other living beings in the audience. Everybody has another focus on the argument, either by understanding or by performing, or by remembering a speech. The mode in which those 'errors', those changes may happen is on the one hand the mode of firstness. Quality of feelings, individual experiences, as state of chance attribute a certain vagueness to the thirdness - as vagueness inside the performing or understanding of an argument, reading a written text, or hearing a speech. The other possibility to change lies in the repetition process, which happens as presymbolic process, as play between immediate and dynamic symbolization during the process of constant repetition. Depending on the different players, as performers or recipients, different versions, varying variants are created.

In contrast, even if certain convictions or beliefs are installed, and pretended absolute ideas or systems are created out of a process of repetition, sameness is not possible neither in live nor in performance, neither in an artistic nor in a rational process, because of those small errors, those little changes sneaking in. Even in Peirce's semiotics, firstness and thirdness constantly change places in the course of the time of the semiosis. And that refers to the symbol of the immediate object having origin in that process. However, the immediate object refers to the dynamic object changing in time and space. And the dynamic object constantly is influenced by changes, due to the context of life. Unless otherwise it will be restricted by a final concept, a final interpretant!

\subsection{Deconstruction}

There are changes on the object level of the interpretant. Immediate and dynamic objects are set into a creative relation! In Peirce categories it is a repetition with changing images and a play between dynamic and immediate symbols of the objects.

Due to a certain relativeness of the created structures, one can use them to stage and play with them. In this part of the performance, created structures are combined with other structures, which are personal ones of the performers. The play is as a movement where one structure cannot get a fixed meaning, but the power of the meaning dissolves in the deconstructing process. Here, the frottage of different layers impels the deconstruction, in which the result is unknown: there are a variety of meanings arising in analogy to the former ones. And each meaning creates a pathway to follow. 


\section{Conclusion}

\section{New Modes of thinking: Dancing bodies and body-thinking!}

\section{The democratic impulses of dancing bodies: Creation, Co-operation: Transversal Freedom}

The democratic impulses of dancing bodies can be seen in the co-creation of a transversal space, in which 'transversal freedom' of many and of differences might be possible. This happens because of the release of power relations in the mode of communication. As we have seen that mode of communication is a cognitive shift happening in the mode of 'play' in life, in dance or/and in the art of performance by the mode of frottage. In the frottage of the layers of different media, each medium, each subject, becomes porous. The borders of each one opens and out of this interaction of 'Other' realities, other entities are created, which becomes birth only in this transversal interaction of the different subjects.

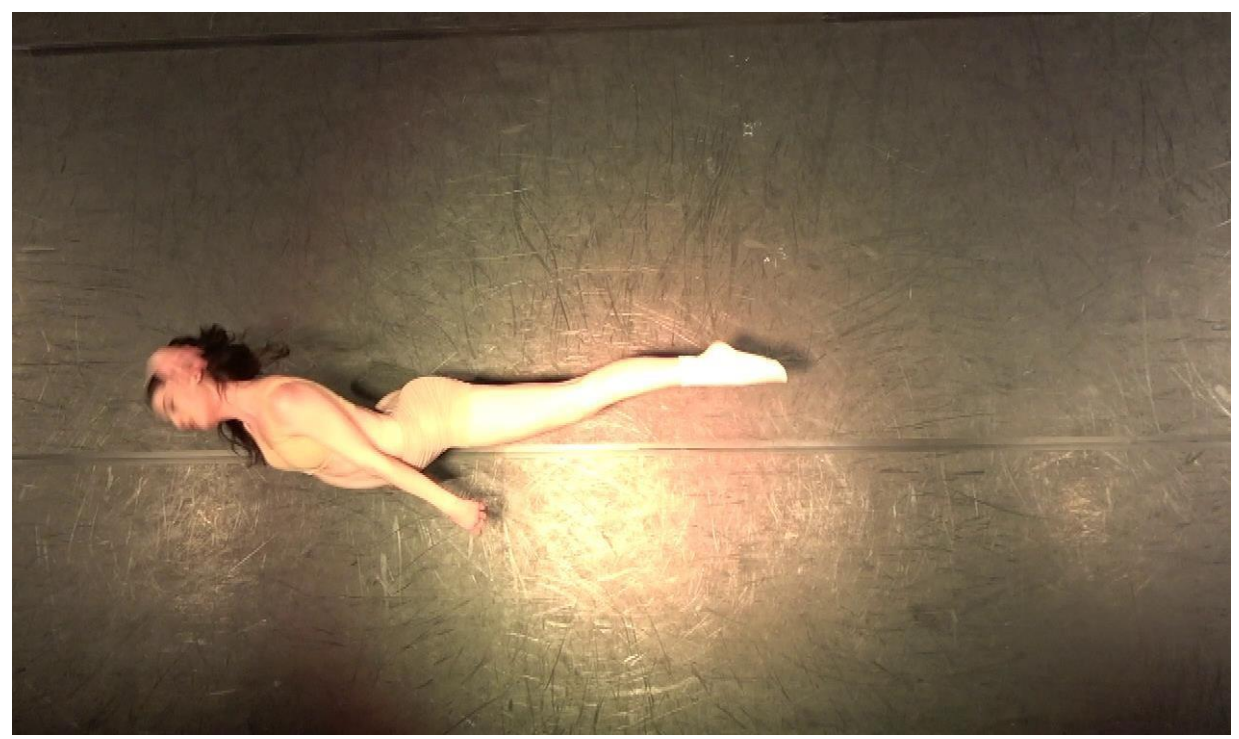

Karoline Ruf in 'Dancing bodies as impulses for Democracy'. Photo: Aurelia Baumgartner

That transversal mode opens the borders of eachsubject to 'trans-vertere' to the other and coming back to oneself with enhanced experience as a reflected play with one's feelings, thoughts, and impressions and with them of the other. In that state of transversal, everybody makes new experiences and has the possibility to open their minds to new perspectives on terms or concepts, which before seemed to be fixed and unchangeable. Thus, there might be access to new modes of thinking and interacting with the other than us. 


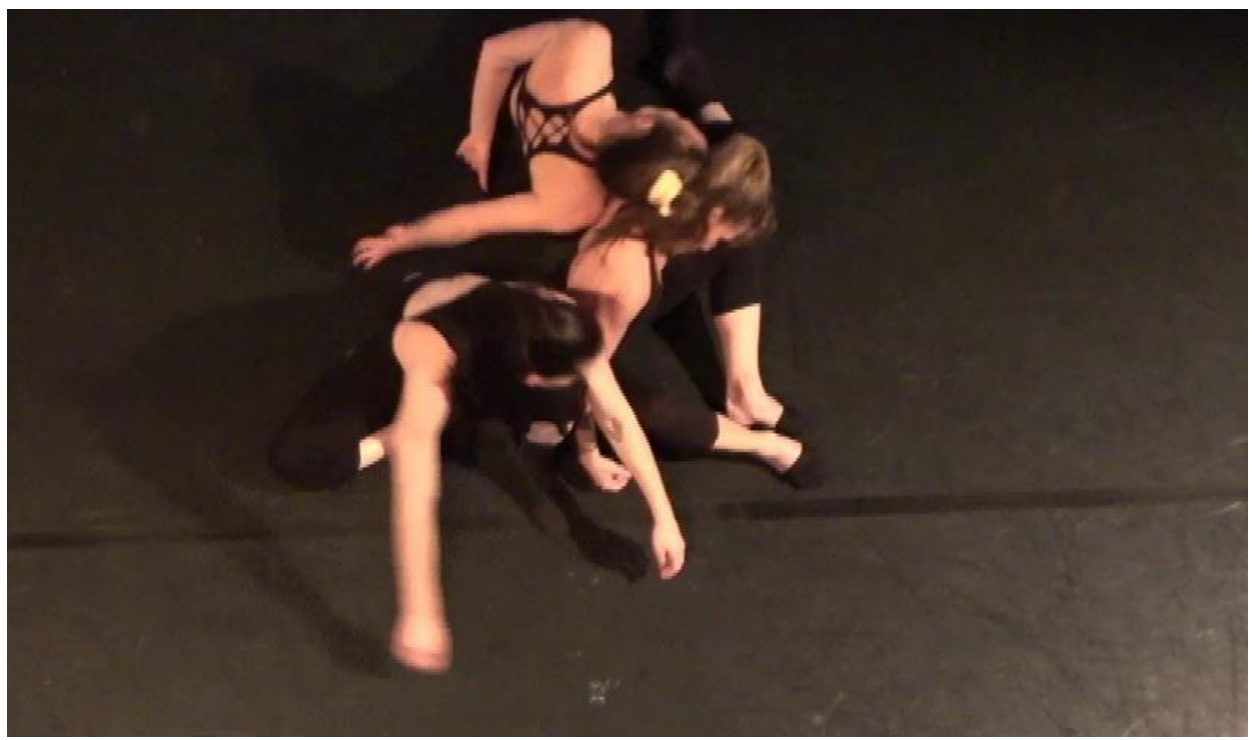

Karoline Ruf, Ina Bures, Raphaela Baumgartner in 'Dancing bodies as impulses for Democracy'. Photo: Aurelia Baumgartner

As I have demonstrated before analyzing what semiotically happens there, the release of power relations is caused by the release of a final interpretant and thus, by the release of the dominance of bringing together the immediate and the dynamic object in fixed symbols. This shows that it is necessary to give up the impetus of finality in terms. That change of focus in the mode of the interpretant, in Peirce's terminology in the mode of thirdness, makes a difference as well to the result of the same dance-and movement techniques as do Contact Improvisation or Taiji or Yoga - applied by Totalitarian Regimes; as it is the case in contemporary China, Russia and others. If you have a fixed aim in the application, those techniques, the release, and liberation potential of those movement techniques are successful only until they reach the achievement of a certain goal. Here, what is not applied is the power of judgement in the mode of firstness, called Abduction, which provides a huge scope of experimental freedom to invent a rule which does not yet exist and projects it in the long run. Rather, totalitarian states operate out of the fixed statement of secondness, whose power of judgement is called Deduction, deducing the consequences and applications of an already given rule achieved by the power of judgement of thirdness, but effectuated as fixed statement of a rule in the mode of secondness, as I explained before as dici sign. Then in the mode of thirdness, on the interpretant level, Induction only examines and confirms the rule.

Usually, power relations are imposed either by authority, by physical force or by the rational power of the creation of absolute categories. All those, authority, physical force, and the rational discourse exclude the 'Other' - an Other that does not fit in with the principles imposed by the rational rules of the discourse community! Power relations are due to the intentionality and 
authority of the subject. In relation to disciplinarian images on bodies, they are like fixed symbols, here as body images created throughout a final process. As such, they become a social reality; however, as we have seen, they are only a creation and not an absolute $a$ priori.

Freedom is related to intentionality and has the intrinsic problem of the authority of a sovereign. It is authority, as an outstanding, or intrinsic a priori absolute rule imposed on free decision-making. If such a rule is applied, freedom in its structure, as an intrinsically free and spontaneous act risks to end. Here one main problem of freedom and sovereignty is touched.

The problem is the following: the power of democratic authority should be associated with the freedom of subjects of a community as many different voices. It is a practical relation of different intentional will power of subjects expressed in a common law. Each law has a notion of unification and absolutization, and therefore of exclusion. Freedom risks to end if the possibility of its change, of otherness in each moment of rule application, will not be integrated. Intentionality in a higher activated state of firstness, in combination with the knowledge of a deconstructive standpoint intrinsic to the constitution of symbols, terms, arguments, and general rules, as figured out in my argumentation above, concerning deconstruction in the mode of an oscillation of immediate and dynamic object of the symbol, may be the key to a 'freedom in motion', a freedom for many different others, to a 'transversal freedom'!

This constant movement of change within rule constitution and rule application can be experienced by a body and mind integrated thinking and acting, a thinking and acting in motion with enhanced perception, a sensing, feeling thinking based on the creative and transformative, the deconstructive power of body-thinking.

It is like softening our gaze, which usually forms our linear understanding to enter in a coauthor's standpoint and take over a co-creator's view of the whole scenery happening and creating at the same time. Out of a unique flickering frame of a scenery the imagination will be opened, capturing parts and the whole at the same time. That is like a widening up of consciousness.

As I tried to show, body-thinking as experienced by dancing bodies in performance, might open a realm for a non-hierarchal interaction, as a co-operative, innovative, co-creation by transversal subjects of a 'transversal space', in which 'transversal freedom' might be possible. In the best cases it might be a way to a co-operative world of free and respectful togetherness of many different voices and beings.

"Nuovi ricordi vuoti come la terra, con contenuti in arrivo"10

\footnotetext{
${ }^{10}$ (Aurelia Baumgartner in 'Materie Prime', Performance with Silvio Cattani, 2017, Rocca di Umbertide, Italy)
} 

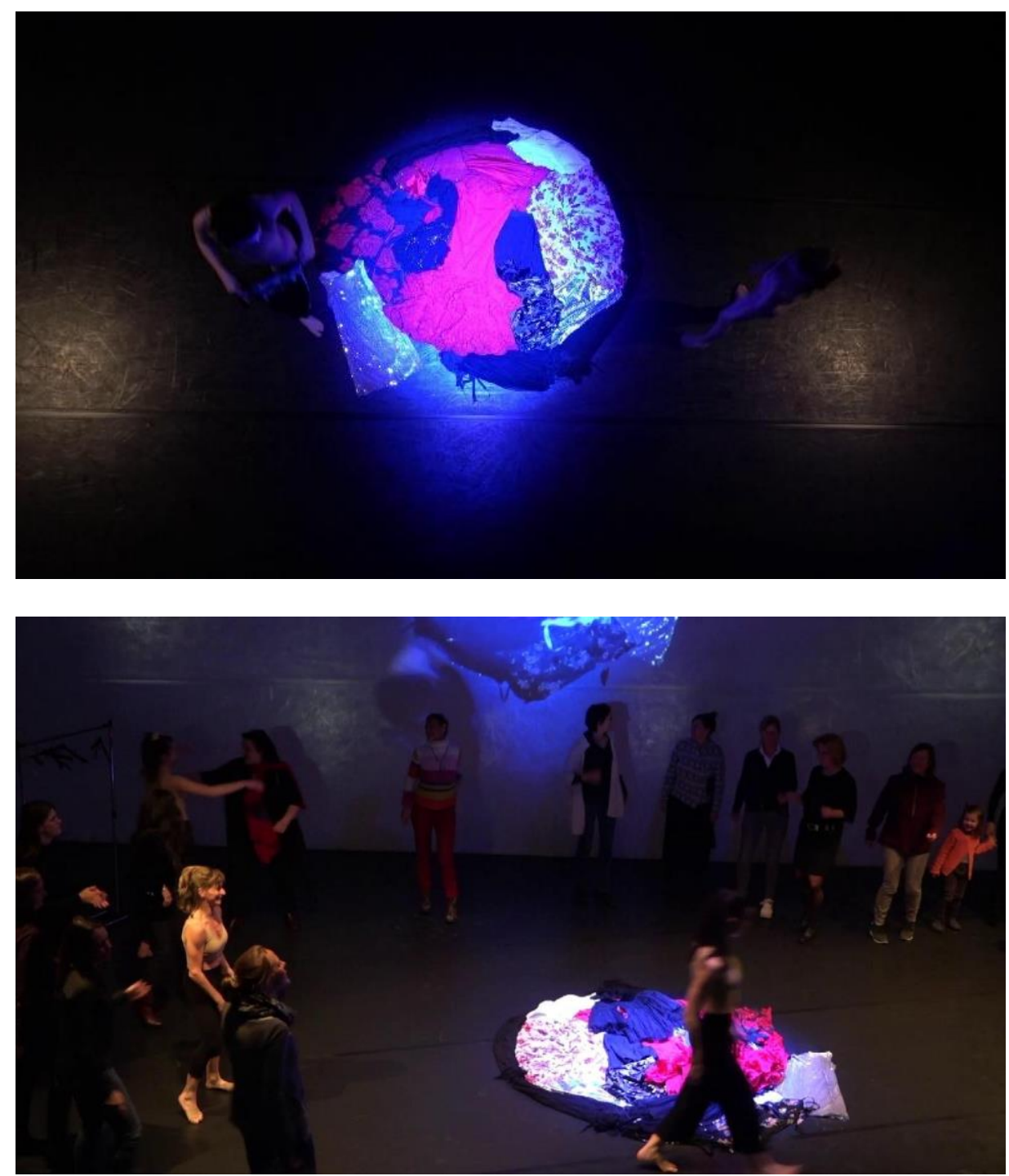

\section{References}

Agamben, G. (2016). Homo Sacer: Die moderne Macht und das nackte Leben. (11. Auflage). Frankfurt a. M.: Suhrkamp.

Aristoteles. (2012). Politik. (Phil Bibliothek, Bd.616) hrsg. Eckart Schütrumpf. Hamburg: Felix Meiner.

Arendt, H. (2015). Macht und Gewalt (25. Auflage). München/Berlin: Piper. 
Baumgartner, A. (2016). Catch me if you can! - Eurydice 2012 Reloaded: Notes on the Performance, in Meyer-Dinkgräfe, D. (Ed.). Consciousness, Theatre, Literature and the Arts (pp. 1-16). Newcastle: Cambridge Scholars Publishing.

Baumgartner, A. \& Meyer-Dinkgräfe, D. (2019). Spirituality in Aurelia Baumgartner's Tanzphilosophie. In Williamson, A. \& Sellers-Young, B. (Eds.). Spiritual Herstories (pp. 504-523). Bristol: Intellect.

Bergman, M., \& Paavola, S. (Eds.) (2003). The Commens Dictionary of Peirce's Terms. Peirce's Terminology in His Own Words. http://www.helsinki.fi/science/commens/dictionary.

Brodocz, A., Schaal, G. S. (Hrsg.). (2016). Politische Theorien der Gegenwart II. ( 4. Auflage). Opladen \& Toronto: Verlag Barbara Budrich.

Butler, J. (2017). Die Psyche der Macht: Das Subjekt der Unterwerfung. (9. Auflage). Frankfurt a. M.: Suhrkamp.

Cooper, R. (2008). [Corpora-List] Peirce 's: ON A NEW LIST OF CATEGORIES. Source: listserv.linguistlist.org/pipermail/corpora/2008-July/012170.html

Derrida, J. (2017). Gesetzeskraft: Der "Mystische Grund der Autorität” (8. Auflage). Frankfurt a. M.: Suhrkamp.

Derrida, J. (1992). Das andere Kap: Die vertagte Demokratie (1. Auflage). Frankfurt a. M.: Suhrkamp.

Derrida, J. (2019). Schurken: Zwei Essays über die Vernunft. Frankfurt a. M.: Suhrkamp.

Derrida, J. (1967). L'ecriture et la difference. Paris: Editions du Seuil.

Derrida, J. (2015). Politik der Freundschaft. (4. Auflage). Frankfurt a. M.: Suhrkamp.

Descartes, R. (1977). Meditationes de prima philosophia. Hrg. Lüder Gäbe, durchgesehen Hans Günther Zekl. Hamburg: Felix Meiner.

Deleuze, G./Guattari, F. (1980). Capitalisme et schizophrénie 2: Mille plateaux. Paris: Les editions de Minuit. www.duden.de Duden online 2016.

Foucault, M. (1987). Sexualität und Wahrheit I: Der Wille zum Wissen. Frankfurt a. M.: Suhrkamp.

Foucault, M. (1978a). Dispositive der Macht. Berlin: Merve.

Foucault, M. (2017). Die Ordnung des Diskurses. (14. Auflage). Frankfurt a. M.: Fischer.

Foucault, M. (2006). Sicherheit, Territorium, Bevölkerung: Geschichte der Gouvernementatlität I. Vorlesungen am College de France 1977/78. Frankfurt a. M.: Suhrkamp.

Habermas, J. (1988), Der philosophische Diskurs der Moderne. Frankfurt a. M.: Suhrkamp.

Hobbes, Th. (2017). Leviathan. (16. Auflage). Frankfurt a. M.: Suhrkamp.

Hookway, Ch. (1985). Peirce. London: Routledge \& Kegan Paul.

Kant, I. (1985). Kritik der praktischen Vernunft. (1797-Originalausgabe). Hamburg: FelixMeiner.

Kant, I. (1956). Kritik der reinen Vernunft. (1.Aufl. A, 1781 \& 2.Aufl. B 1787). Hamburg: Felix Meiner. 
Kant, I. (1974). Kritik der Urteilskraft. (Ausgabe von 1790). Hamburg: Felix Meiner.

Korten, D. C. (2006). The Great Turning: From Empire to Earth Community. San Francisco,CA: Berrett- Koehler Publisher, Inc.

Korten, D. C. Seeking the pathway to a future that works for all. Home/ A Great Turning: The Process. Living Economics Forum: Yes! magazine, online.

Macy, J. and Young Brown, M. (1998). Coming Back to Life: Practices to Reconnect Our Lives, Our World. Gabriola Island, BC, Canada: New Society Publishers.

Myers, D. G. (2007). Psychology. New York: Worth Publishers.

Nida-Rümelin, J. (2016). Demokratie als Kooperation. (2. Auflage). Frankfurt a.M.: Suhrkamp.

Peirce, C. S., and Welby G., V. (Lady Welby). (1977). Semiotic and Significs: The Correspondence between C. S. Peirce and Victoria Lady Welby, (ed) Charles S. Hardwick. Bloomington and Indianapolis: Indiana University Press.

Peirce, C. S. (1893-1913). The Essential Peirce: Selected Philosophical Writings. Volume 2. Bloomington and Indianapolis: Indiana University Press.

Peirce, C. S. (1867-1893). The Essential Peirce: Selected Philosophical Writings. Volume 1. Bloomington and Indianapolis: Indiana University Press.

Pape, H. (1983). Charles S. Peirce Phänomen und Logik der Zeichen. Frankfurt a. M.: Suhrkamp.

Pape, H. (2000). Charles S. Peirce Semiotische Schriften. Bd. 1. Frankfurt a.M.: Suhrkamp.

Pennsylvania State University, Psych 256; Cognitive Psychology: SU making connections between theory and reality-> Myers, D. G. (2007). Psychology. New York, NY: Worth Publishers.

Popper, K. (2011). The Open Society and its Enemies. (Revised ed). London: Routledge.

Schönrich, G. (1990). Zeichenhandeln: Untersuchungen zum Begriff einer semiotischenVernunft im Ausgang von C. S. Peirce. Frankfurt a. M.: Suhrkamp.

Schönrich, G. (1999). Semiotik zur Einführung. Hamburg: Junius.

Seif, F. Y. (2005). Social Change in the 'Aperspectival World': The Paradox of social Reproduction and Cultural Innovation." In TRANS. Internet-Zeitschrift für Kulturwissenschaften. No.16/2005.WWW: Http://www.inst.at/trans/16Nr/01_2/seif16.htm.

Shlain, L. (1998). The Alphabet Versus the Goddess: The Conflict Between Word and Image. New York: Viking Penguin.

Thompson, E. (2007). Mind in Life: Biology, Phenomenology, and the Sciences of Mind. Cambridge, Massachusetts. London, England: The Belknap Press of Harvard University Press.

Welsch, W. (1996). Vernunft. (1. Auflage). Frankfurt a. M.: Suhrkamp. 


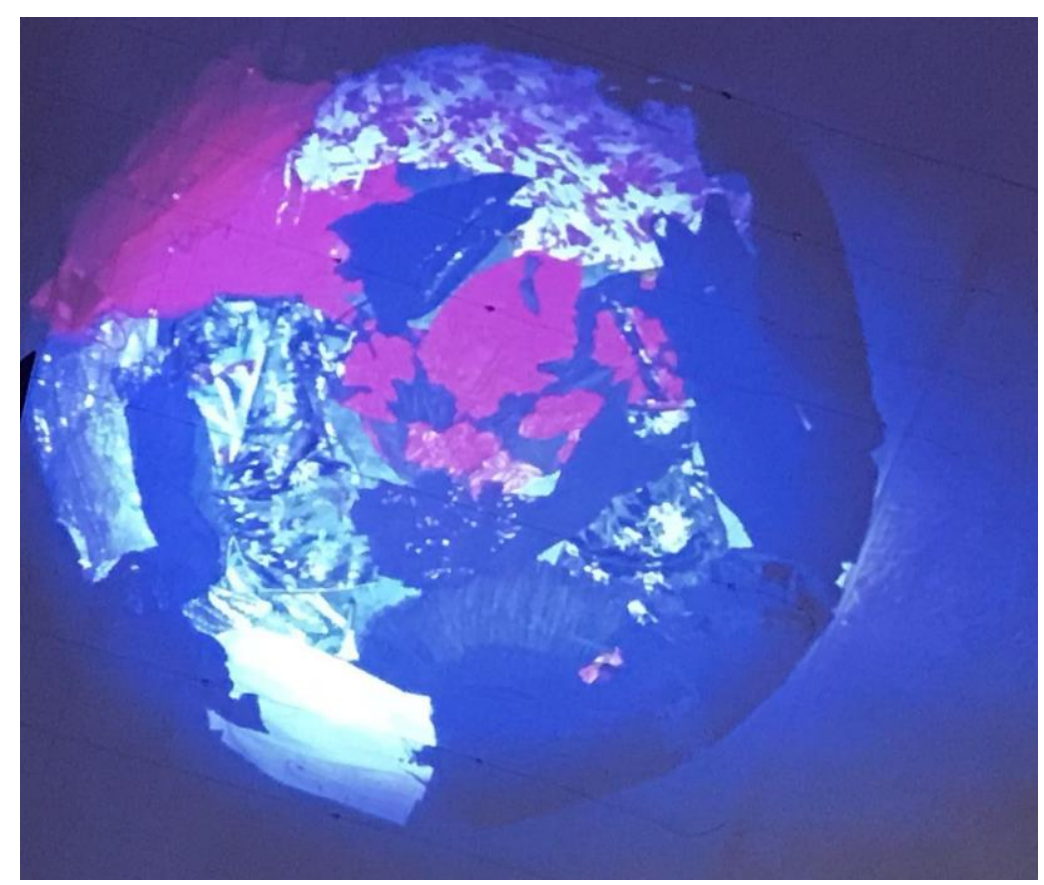

Photographer of the last 3 photos: Aurelia Baumgartner

Link to a compilation of the Performance at youtube channel Philocast: https://www.youtube.com/watch? $v=$ FsImy1DoaHO 